\title{
Debates
}

\section{LAS EXPERIENCIAS DE LAS REIVINDICACIONES}

A veces, el afán por hacer un proselitismo rápido, cuya necesidad se compensaría si existiera una muy buena formación dinámica sindical, lleva al "liderazgo" a realizar los análisis más simplistas y a difundir como consignas entre sus bases, reivindicaciones totalmente contradictorias.

Desafortunadamente esto ocurre con los sindicatos de la educación, cuyo principal índice de inoperancia es la escasez, aferramiento y casi nula renovación de cuadros directivos, así como la tendencia de los mismos a cambiar beligerancia por posiciones -también burocráticas- en los entes educativos oficiales.

No es lo mismo que la asamblea general de afiliados de un sindicato determine como estrategia de negociación con el Estado el presentar plataformas políticas para la educación, o el formular criterios para la selección, o el presentar y apoyar candidatos o el formar comisiones de interlocución permanente con las altas esferas decisorias, a que en el curso de estrechas negociaciones entre una junta directiva y el ministerio o secretaría de turno, los supuestos "líderes sindicales" resulten convertidos en patronos oficiales del cuerpo docente de la noche a la mañana y, lo que es peor, que asuman de buen grado esa actitud.

El sindicato docente vivió desde hace algunos años, un reencauche ante sus bases, cuando decidió asumir responsabilidades en lo que se llamó el "Movimiento Educativo" llegando a configurar como uno de los puntos de su programa de lucha la calidad de la educación.

En ese contexto, resulta difícil comprender cómo se vuelve consigna sindical el evadir la evaluación del desem. peño, en 1996 o la presentación del PEI en 1997.

Las recientes negociaciones para levantar el paro nacional del magisterio, se nos comunicaron a la opinión pública como un parte de victoria de los dos implicados: el sindicato y el gobierno. El sindicato reportó haber triunfado (al respecto) al conseguir la no exigencia de los PEI en el plazo fijado y la total eliminación de sanciones por su carencia. Por otra parte, el gobierno informa su éxito en la negociación por cuanto el sindicato se comprometió a que los docentes presentarán -léase bien-actualizaciones anuales del PEI.

Se requiere ser muy ingenuo o estar totalmente ajeno a los intereses educativos para creer de buena fe que cualquiera de las versiones se refiere a una conquista:
¿Qué ganan la educación, los estudiantes y los padres de familia con que se escamotee la evaluación de desempeño de los maestros?

- Si se supone que el movimiento educativo los consagró como adalides de la calidad de la educación, ¿no son ellos los primeros interesados en decodificar y demostrar su idonedidad para ejercerla?

- ¿Su lealkad a la causa educativa, no los conmina a desear que "sean todos los que están y estén todos los que son?

- ¿Un examen de idoneidad, no es la modalidad óptima para definir las actuales necesidades de capacitación para los nuevos retos que la educación impone?

- ¿Hasta cuándo están dispuestos los docentes preparados responsables y consagrados, a sobrellevar el doble lastre de la mala fama y de la irresponsabilidad de otros, que a ellos les endosa las complicaciones disciplinarias, las dificultades con estudiantes impreparados, la malquerencia de los padres de familia y la mala conciencia de encubrir a gentes desobligadas?

- ¿Se gana realmente tanto, como educador y como persona al renunciar al derecho de opinar para llevar a efecto una educación mejor que aquella a la que se han visto obligados?

- ¿Es una verdadera ganancia para el país (y no digamos para el gobierno) el convertir en planes de inversión a un año -tal como ocurrió con los planes de desarrollo que la Constitución ofreció a los municipios- los ambiciosos proyectos educativos que tanto sofnamos con la Ley General de Educación y que se suponía iban a cristalizar la genuina participación comunitaria en el manejo de nuestros destinos?

Es alarmante que la educación se esté carcomiendo desde adentro, por causa de la inconsciencia de todos los que creen que el compromiso se reduce a dictar clases de una puerta hacia adentro, para evitar un despido; o a dictar normas detrás de un escritorio, para evitar una huelga.

No se trata deque gane un sindicato o un gobierno de paso; en estos autogoles perdió Colombia, ni más ni menos.

Por todas estas razones, maestros, padres de familia, estudiantes, funcionarios políticos. $\mathrm{iOjo}$ a los proyectos educativos institucionales!

\section{Maria Victoria Rodríguez C.}

NOTA: Tomado dela Revista Magazín No725, El Espectador del 6 de abril de 1997, pág. 2 . 